\title{
Drug Skin Rash
}

National Cancer Institute

\section{Source}

National Cancer Institute. Drug Skin Rash. NCI Thesaurus. Code C114280.

An eruption in the skin due to exposure to a pharmacologic substance. 